Кузнєцова Т. В. ${ }^{(1 ;}$ ORCID ID: 0000-0003-2361-2019),

к.е.н., професор,

Лесняк О. Ю. (1; ORCID ID: 0000-0001-7223-6352) к.е.н., доцент,

Красовська Ю. В. (1; ORCID ID: 0000-0002-5786-3267) к.е.н., доцент,

Подлевська О. М. (1; ORCID ID: 0000-0003-4979-9282) к.е.н., доцент

${ }^{1}$ Національний університет водного господарства та природокористування, м. Рівне

\title{
ОЦІНКА ДИНАМІКИ ЗАГАЛЬНОЇ ФАКТОРНОЇ ПРОДУКТИВНОСТІ СІЛЬСЬКОГО ГОСПОДАРСТВА В УКРАЇНІ
}

Розкрито важливість розширеного трактування економічної категорії продуктивності за допомогою показника загальної факторної продуктивності. Для оцінки співвідношення сукупного показника випуску продукції з витратами ресурсів використано індексний підхід. Оцінено індекси виробництва сільськогосподарської продукції та індекси собівартості сільськогосподарського виробництва. Показано динаміку рівня загальної факторної продуктивності сільського господарства в Україні. Відображено зниження ефективності аграрного сектору при нарощуванні обсягів виробництва в абсолютних показниках.

Ключові слова: економічне зростання; фактори виробництва; індексний підхід; загальна факторна продуктивність; сільське господарство.

Постановка проблеми. Поняття продуктивності традиційно асоціюється з процесом використання трудових ресурсів. При цьому результативність використання інших факторів виробництва часто аналізується узагальнено і не дозволяє зробити деталізованих наукових висновків. Активізація використання в економічних дослідженнях категорії загальної факторної продуктивності дозволила б виявити не лише загальну динаміку економічних результатів, але й ідентифікувати їі чинники.

У сільському господарстві аналіз рівня використання ресурсів може надати об'єктивну інформацію про основні причини збільшення або зменшення обсягів виробництва сільськогосподарської продукції і бути основою для розробки заходів державного регулювання аграрного сектору. 
Аналіз останніх досліджень та публікацій. Питання продуктивності $€$ одними з базових в економічних дослідженнях і тому їм присвячено цілий ряд праць таких відомих економістів, таких як Дж. Хікс, Дж. Е. Мід, Р. Солоу, М.Браун, К. Фаглі, С. Ванг, Дж. Алстон та ін. 3 українських досліджень варто відмітити публікації В.Я. Гуменюка, А.О.Касіч, Н. В.Статівки, в яких розглядаються питання збільшення продуктивності, підтримування якості економічного зростання, пошуку можливостей позитивних структурних зрушень у господарських системах. Багатофакторні моделі аналізу продуктивності розглядаються у роботах О. Мороза і Л. Штефан, С. Лучанінова, С. Волошиної, С. Семенова та Н. Ларичевої.

Основні методичні підходи до оцінювання загальної факторної продуктивності саме у сільському господарстві розроблені такими дослідниками, як Кумар (2008) та Фуглі (2010) [1; 2]. У роботах Гуменюка В. Я. та Статівки Н. В. [4; 5] були розглянуті багатофакторні моделі аналізу продуктивності як такі, проте динаміка цього показника для українського аграрного сектору і чинники, які на нього впливали, потребують подальшого розгляду.

Останні дослідження динаміки цього показника вказують на сповільнення зростання продуктивності в сільському господарстві в розвинених країнах, особливо у зерновій галузі (2014) [3]. Слід проаналізувати, чи такі ж тенденції до сповільнення ефективності аграрного виробництва присутні і в Україні.

Постановка завдання. Метою дослідження $€$ оцінювання динаміки загальної факторної продуктивності. Для досягнення поставленої мети аналізуються такі показники як валовий дохід сільськогосподарських підприємств, індекс фізичного обсягу продукції сільського господарства та співставлення індексів обсягів та індексів собівартості, порівняння динаміки яких дозволить апробувати методичні підходи до визначення загальної факторної продуктивності сільськогосподарського виробництва, об'єктивно оцінити джерела економічного зростання аграрного сектору в національній економіці України.

Основним завданням $€$ оцінка загальної продуктивності в сільському господарстві, яка б показала, внаслідок зміни котрих 3 чинників виробництва відбувається зростання або падіння реальних обсягів сільськогосподарської продукції.

Останнім часом методика визначення багатофакторної продуктивності все більш жваво залучається до глобальної економічної дискусії, проте в Україні вона висвітлена не повністю. Показник загальної факторної продуктивності дозволяє одночасно оцінити внесок багатьох чинників коливання обсягів виробництва і 
набув важливого значення у поясненні довгострокового зростання, оскільки загальна факторна продуктивність відображає спільний вплив багатьох чинників на результат.

Виклад основного матеріалу. Оскільки аграрне виробництво $€$ однією 3 визначальних галузей національної економіки нашої держави, його економічне зростання $\epsilon$ визначальним для формування передумов зростання ВВП країни і зрештою зростання добробуту населення. На це впливає цілий ряд чинників. Позитивними чинниками, на нашу думку, $€$ загальна тенденція до зростання глобального попиту на сільськогосподарську продукцію та сприятливі природно-географічні умови для розвитку сільського господарства в нашій країні. Факторами, залучення яких є критичним та потребує ретельного планування, $€$ ефективне використання сільськогосподарської техніки, оптимізація та модернізація агротехнічних заходів, включаючи внесення добрив та засобів захисту рослин, використання трудових ресурсів тощо.

Якщо нарощування виробництва оцінювати виключно на основі показника динаміки чистого доходу сільськогосподарських підприємств, то можна спостерігати постійне та стрімке нарощування обсягів починаючи з 2000-х років. Проте динаміка показників обсягу у вартісному виразі не дозволяє об'єктивно оцінити природу зростання. Індексний аналіз на основі натуральних показників дозволяє виключити вплив цінових та інфляційних чинників, якого не можна уникнути при використанні вартісних показників. Якщо аналізувати обсяги виробництва продукції сільського господарства у натуральному виразі, то на основі даних Державної служби статистики, економічне зростання можна спостерігати далеко не у всіх періодах аналізу [9]. Як видно на рис. 1, динаміка цього показника була стрибкоподібною. На нашу думку, це пов'язано як 3 періодичними фінансово-економічними проблемами економічного розвитку країни, зокрема і в сільському господарстві, так і 3 змінними природними погодно-кліматичними умовами. В 1998, 2003, 2007, 2010 та 2016 роках відбувається спад виробництва. Загалом же значення індексів вищі від 100 \%, що доводить наявність факту економічного зростання в українській аграрній сфері (рис. 1). 


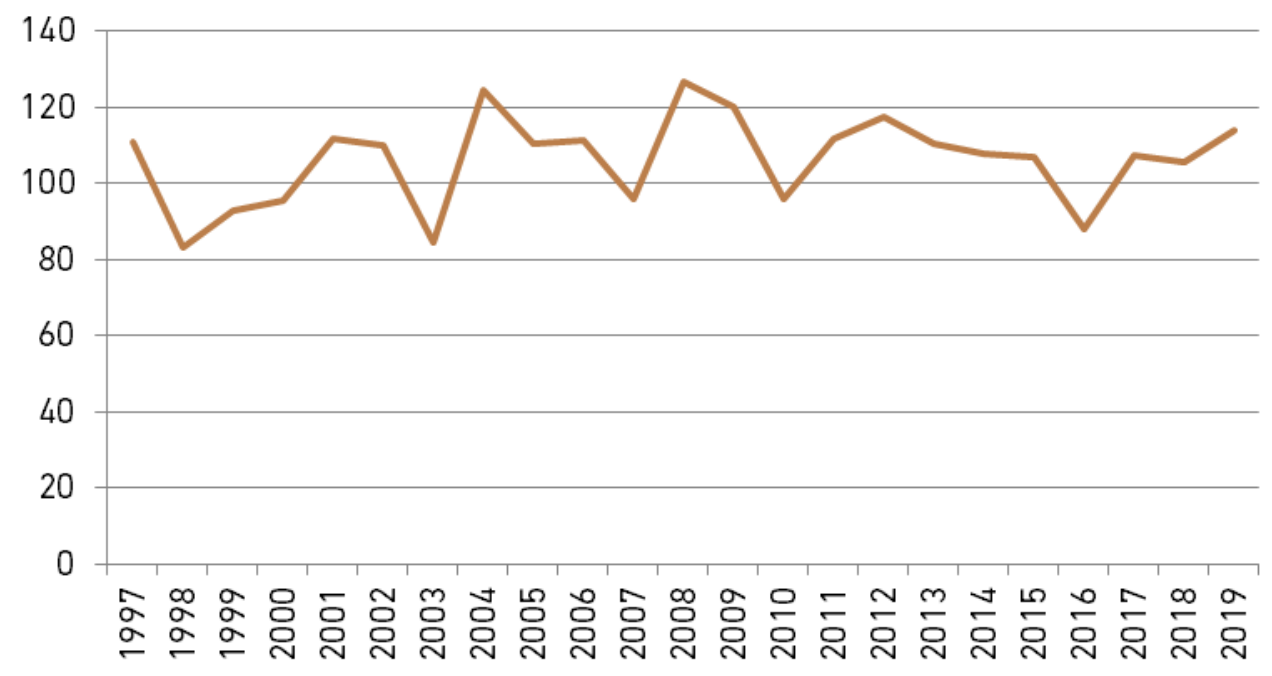

Рис. 1. Індекси фізичного обсягу продукції сільського господарства, реалізованої підприємствами (1997-2019) (у \% до попереднього року) Джерело: [8]

Якщо порівнювати цю динаміку з показниками розвинутих країн світу, зокрема із країнами Західної Європи, США, Японією та Австралією, то сільське господарство в Україні зростало швидшими темпами. В цих країнах виробництво сільськогосподарської продукції в останні два десятиліття не лише не зростало, але і подекуди знижувалося [6; 7].

При цьому важливо оцінити, чи джерелом економічного зростання було збільшення продуктивності, чи екстенсивне акумулювання факторів виробництва. Оцінка загальної факторної продуктивності, яка полягає у вимірюванні і аналізі динаміки продуктивності виробничих ресурсів на основі статистичної інформації про обсяги продукції та затрати ресурсів певною виробничою системою, $з$ нашої точки зору, дозволяє дати відповідь на це запитання.

Сам факт зниження чи нарощування обсягів продукції сільського господарства, навіть у натуральних показниках, не може свідчити про зниження чи нарощування ефективності. Оцінюючи загальну факторну продуктивність сільського господарства недостатньо проаналізувати динаміку обсягів виробництва сільськогосподарської продукції. її слід порівнювати з динамікою обсягів залучених для ії̈ виробництва ресурсів. Саме лише зростання обсягів виробництва в жодному разі не може свідчити про досягнення ефективності. 
Загальна факторна продуктивність оцінюється співвідношенням сукупного показника випуску з набором ресурсів, що аналізуються [10]. Нами пропонується використовувати для аналізу не порівняння абсолютних значень вищевказаних факторів, але динаміку індексів. Як було відмічено вище, щоб оцінити ефективність роботи певного сектору, потрібно оцінити відносний показник, який би показував співвідношення між економічним ефектом та спожитими для його досягнення виробничими ресурсами. Оцінюючи загальну факторну продуктивність сільського господарства, слід співставити індекси виробництва сільськогосподарської продукції та індекси собівартості сільськогосподарського виробництва. При врахуванні специфіки сільського господарства саме такий підхід $є$ більш виправданим, ніж класичне оцінювання однієї лише продуктивності праці. । покращання посівного матеріалу, і зміна структури сортів та сівозміни, і зміна обсягів та структури використання засобів захисту рослин, тобто саме багатофакторність - впливає на кінцевий результат. Навіть якщо індекси обсягів збільшуватимуться, проте індекси собівартості зростатимуть більшими темпами, то загальна ефективність спадатиме.

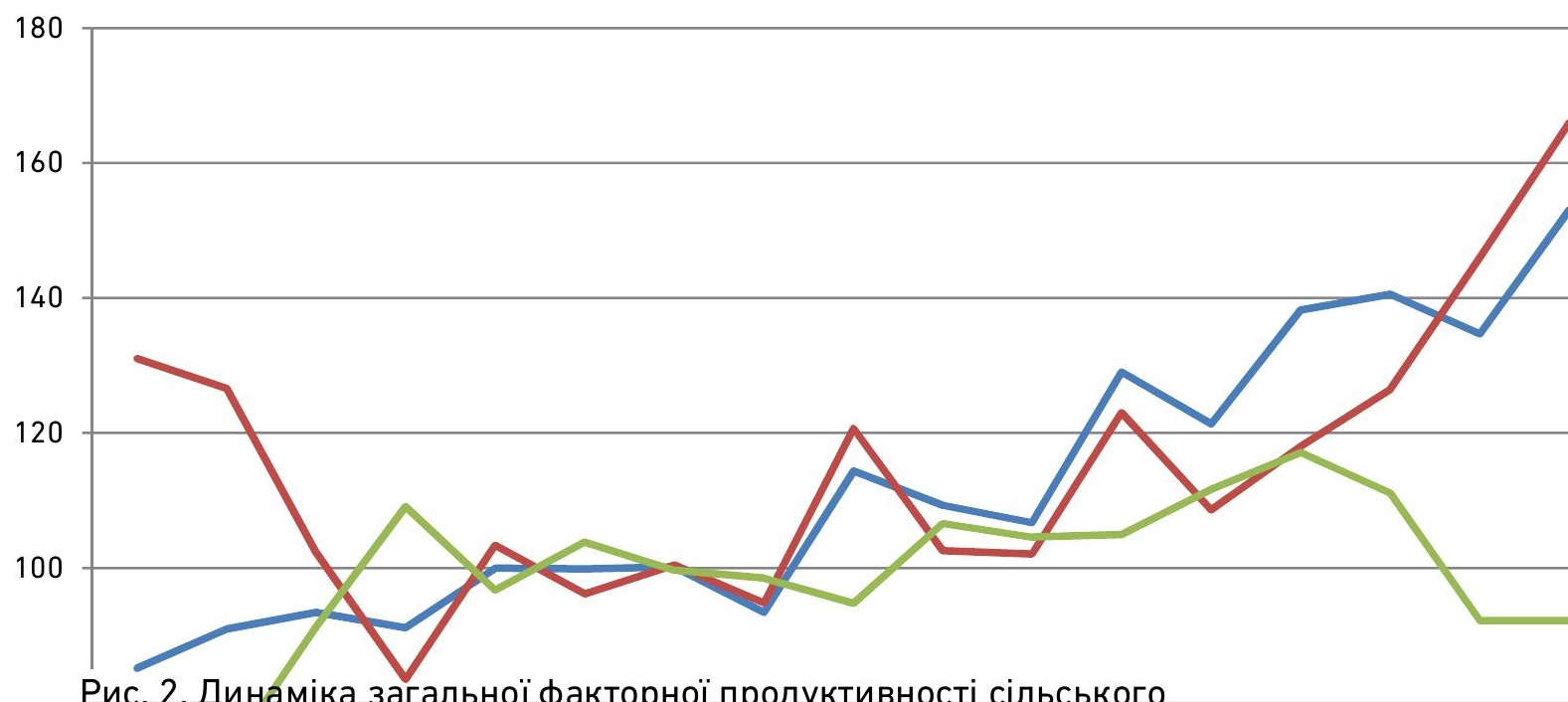

Рис. 2. Динаміка загальної факторної продуктивності сільського господарства України в 2000-2016 рр. (2004 - 2006 = 100\%)

Джерело: власні розрахунки авторів на основі FAOstat, Державний комітет статистики України

На рис. 2 ми бачимо, що індексний аналіз також свідчить про те, що продукція сільського господарства зростала стрімко не лише в період 2008-2014 років, але в подальші роки. При розрахунку ж 
загальної факторної продуктивності нами було обрано сукупну продуктивність (співвідношення сукупного показника випуску 3 набором ресурсів, що аналізуються). На рисунку показано порівняння динаміки індексів виробництва 3 динамікою індексів собівартості. В роки, коли індекс виробництва перевищував індекс собівартості, можна стверджувати про досягнення нарощування продуктивності в сільському господарстві. Якщо ж навпаки індекси собівартості були вищими, то такі роки слід вважати неефективними. Причому це не пов'язано із наявністю чи відсутністю самого факту економічного зростання, оскільки навіть при зростанні обсягів, як було вже відмічено раніше, продуктивність може знижуватися, i навпаки. Кінцевим критерієм є динаміка кривої загальної факторної продуктивності. Як бачимо, починаючи з 2014 року значення цього показника вказують на спад економічної ефективності сільськогосподарського виробництва, а з 2015 року він $\epsilon$ нижчим від одиниці.

Висновки. На основі проведених досліджень можна зробити такі висновки. Динаміка показника загальної факторної продуктивності сільського господарства України знижується. Загальна факторна продуктивність, що нижча від 100\%, вказує на те, що не дивлячись на нарощування індексів виробництва продукції сільського господарства, зростання більш високими темпами індексів собівартості ідентифікує негативні тенденції динаміки ефективності розвитку аграрного сектору. Не дивлячись на позитивні індекси виробництва, які саме в цей період показують значне зростання, загальна факторна продуктивність має тенденцію до зниження. Причиною цього $\epsilon$ ще більш стрімке зростання обсягів вкладених у сільськогосподарське виробництво ресурсів. В останні роки показник загальної факторної продуктивності не тільки не зростає, але і знижується.

Така тенденція актуалізує питання аналізу причин зменшення ефективності і пошуку джерел подальшого економічного зростання у сільському господарстві України. Таке дослідження можна здійснити за допомогою аналізу багатофакторної продуктивності сільськогосподарського виробництва, дослідження якої буде предметом наступних публікацій.

1. Praduman Kumar, Surabhi Mittal, Mahabub Hossain. Agricultural Growth Accounting and Total Factor Productivity in South Asia: A Review and Policy Implications. Agricultural Economics Research Review. July-December 2008. Vol. 21. Pp. 145-172. URL: https://econpapers.repec.org/article/agsaerrae/47669.htm. (дата звернення: 20.01.2019). 2. Fuglie, Keith. Total factor productivity in the global agricultural economy: evidence from FAO Data. The Shifting Patterns of Agricultural 
Production and Productivity Worldwide. The Midwest Agribusiness Trade Research and Information Center, lowa State University, Ames, lowa, 2010. Pp. 63-95. URL: https://www.card.iastate.edu/products/books/shifting_patterns/pdfs/chapter4.pdf. (дата звернення: 12.10.2018). 3. Ball E., Wang S.L., Nehring R. Productivity and Economic Growth in U.S. Agriculture: A New Look. Applied Economic Perspectives and Policy. March 2016, Issue 1. Vol. 38. Pp. 30-49. URL: https://doi.org/10.1093/aepp/ppv031 (дата звернення: 27.01.2019). 4. Статівка Н. В. Методологічні основи оцінки багатофакторної продуктивності у аграрній сфері. Державне регулювання процесів економічного та соціального розвитку. 2009. Вип. 4 (27). URL: http://www.kbuapa.kharkov.ua/e-book/tpdu/2009-4/doc/3/11.pdf (дата звернення: 27.01.2019). 5. Гуменюк В.Я., Рощик I. А. Менеджмент продуктивності : навч. посіб. Рівне : НУВГП, 2010. 203 с. 6. Fuglie, K., Clancy, M., Heisey, P., and Macdonals, J. Research, Productivity, and Output Growth in U.S. Agriculture. Journal of Agricultural and Applied Economics. 2017. 49 (4), Pp. 514-554. URL: https://www.cambridge.org/core/journals/journal-of-agricultural-and-appliedeconomics/article/research-productivity-and-output-growth-in-usagriculture/75A079865598B5C6BC11C85321E7FBAF (дата звернення: 27.01.2019). 7. Helen Mason. Total factor productivity of the UK agriculture industry. A National Statistics publication. Department for Environment, Food and Rural Affairs. 2019. URL: https://assets.publishing.service.gov.uk/government/uploads/system/uploads/attach ment_data/file/848925/agriproductivity_statsnotice_28nov19.pdf (дата звернення: 01.05.2020). 8. Державна служба статистики України. URL: https://ukrstat.org/uk/operativ/menu/menu_u/cg.htm. (дата звернення: 10.12.2020). 9. Державна служба статистики України. URL: http://www.ukrstat.gov.ua/operativ/operativ2019/sg/ifosg_reagn/ifosg_reagn_97_18 u.htm. (дата звернення: 10.12.2020). 10. Лесняк 0. Ю. Визначення багатофакторної продуктивності сільського господарства. Причорноморські економічні студії. Одеса, 2018. Вип. 30. Ч. 2. С. 10-14.

\section{REFERENCES:}

1. Praduman Kumar, Surabhi Mittal, Mahabub Hossain. Agricultural Growth Accounting and Total Factor Productivity in South Asia: A Review and Policy Implications. Agricultural Economics Research Review. July-December 2008. Vol. 21. Pp. 145-172. URL: https://econpapers.repec.org/article/agsaerrae/47669.htm. (data zvernennia: 20.01.2019). 2. Fuglie, Keith. Total factor productivity in the global agricultural economy: evidence from FAO Data. The Shifting Patterns of Agricultural Production and Productivity Worldwide. The Midwest Agribusiness Trade Research and Information Center, lowa State University, Ames, lowa, 2010. Pp. 63-95. URL: https://www.card.iastate.edu/products/books/shifting_patterns/pdfs/chapter4.pdf.

(data zvernennia: 12.10.2018). 3. Ball E., Wang S. L., Nehring R. Productivity and Economic Growth in U.S. Agriculture: A New Look. Applied Economic Perspectives and Policy. March 2016, Issue 1. Vol. 38. Pp. 30-49. URL: https://doi.org/10.1093/aepp/ppv031 (data zvernennia: 27.01.2019). 4. Stativka N. V. Metodolohichni osnovy otsinky bahatofaktornoi produktyvnosti u ahrarnii sferi. Derzhavne rehuliuvannia protsesiv ekonomichnoho ta sotsialnoho rozvytku. 2009. Vyp. 4 (27). URL: http://www.kbuapa.kharkov.ua/e-book/tpdu/2009-4/doc/3/11.pdf (data zvernennia: 27.01.2019). 5. Humeniuk V. Ya., Roshchyk I. A. Menedzhment produktyvnosti : navch. posib. Rivne : NUVHP, 2010. 203 s. 6. Fuglie, K., Clancy, M., Heisey, P., and Macdonals, J. Research, Productivity, and Output Growth in U.S. 
Agriculture. Journal of Agricultural and Applied Economics. 2017.49 (4), Pp. 514-554. URL: https://www.cambridge.org/core/journals/journal-of-agricultural-and-appliedeconomics/article/research-productivity-and-output-growth-in-usagriculture/75A079865598B5C6BC11C85321E7FBAF (data zvernennia: 27.01.2019). 7. Helen Mason. Total factor productivity of the UK agriculture industry. A National Statistics publication. Department for Environment, Food and Rural Affairs. 2019. URL: https://assets.publishing.service.gov.uk/government/uploads/system/uploads/attach ment_data/file/848925/agriproductivity_statsnotice_28nov19.pdf (data zvernennia: 01.05.2020). 8. Derzhavna sluzhba statystyky Ukrainy. URL: https://ukrstat.org/uk/operativ/menu/menu_u/cg.htm. (data zvernennia: 10.12.2020). 9. Derzhavna sluzhba statystyky Ukrainy. URL: http://www.ukrstat.gov.ua/operativ/operativ2019/sg/ifosg_reagn/ifosg_reagn_97_18 u.htm. (data zvernennia: 10.12.2020). 10. Lesniak 0. Yu. Vyznachennia bahatofaktornoi produktyvnosti silskoho hospodarstva. Prychornomorski ekonomichni studii. Odesa, 2018. Vyp. 30. Ch. 2. C. 10-14.

Kuznietsova T. V. [1; ORCID ID: 0000-0003-2361-2019], Candidate of Economics (Ph.D.), Professor,

Lesniak O. Y. [1; ORCID ID: 0000-0001-7223-6352], Candidate of Economics (Ph.D.), Associate Professor,

Krasovska Y. V. [1; ORCID ID: 0000-0002-5786-3267], Candidate of Economics (Ph.D.), Associate Professor,

Podlevska 0. M. [1; ORCID ID: 0000-0003-4979-9282], Candidate of Economics (Ph.D.), Associate Professor

${ }^{1}$ National University of Water and Environmental Engineering, Rivne

\section{EVALUATION OF THE DYNAMICS OF AGRICULTURAL TOTAL FACTOR PRODUCTIVITY IN UKRAINE}

This paper has reviewed the developments in agricultural productivity related to Ukrainian conditions, namely in the last two decades. Expanded treatment of the economic category of productivity, which in addition to labor includes other factors of production, is essential for the economic research. It is important for the agriculture, where the processes of mechanization and automation occur especially fast. The method of multifactor productivity estimation shows which of the factors of production result in an increase or decrease of real agricultural output.

The growth have been summarized for Ukrainian Agriculture. The base for multifactor productivity calculations is the estimation of total factor productivity. This methodology has been used in international economic discussion to determine whether economic growth is extensive or intensive. The approach used is to estimate the ratio of total output to resource input. At the same time, both indicators are estimated not in absolute terms, but using the index approach. We present the estimation of indices of 
agricultural output and indices of agricultural cost. The graph of dynamics of the level of total factor productivity of Ukrainian Agriculture is based on these calculations and the downward dynamics of the indicator of total factor productivity of agriculture of Ukraine. It reflects the reduction of the effectiveness of the agrarian sector while the volume of production in absolute terms increases. It highlights the importance of analysis of efficiency reduction and the research for sources of further economic growth in agriculture in Ukraine. Such research will be the subject of subsequent publications.

Keywords: economic growth; factors of production; index approach; total factor productivity; agriculture.

Кузнецова Т. В. [1; ORCID ID: 0000-0003-2361-2019] К.э.Н., профессор,

Лесняк А. Ю. [1; ORCID ID: 0000-0001-7223-6352], к.э.Н., доцент,

Красовская Ю. В. ${ }^{[1 ; 0 R C I D ~ I D: ~ 0000-0002-5786-3267] ~}$ к.э.н., доцент,

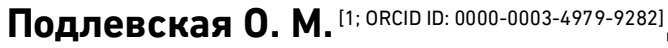
к.э.н., доцент

${ }^{1}$ Национальный университет водного хозяйства и природопользования, г. Ровно

\section{ОЦЕНКА ДИНАМИКИ СОВОКУПНОЙ ФАКТОРНОЙ ПРОДУКТИВНОСТИ СЕЛЬСКОГО ХОЗЯЙСТВА В УКРАИНЕ}

Раскрыта важность расширенной трактовки экономической категории производительности с помощью показателя совокупной факторной производительности. Для оценки соотношения совокупного показателя выпуска продукции с затратами ресурсов использован индексный подход. Оценены индексы производства сельскохозяйственной продукции и индексы себестоимости сельскохозяйственного производства. Показана динамика уровня совокупной факторной производительности сельского хозяйства в Украине. Отражено снижение эффективности аграрного сектора при наращивании объемов производства в абсолютных показателях.

Ключевые слова: экономический рост; факторы производства; индексный подход; совокупная факторная производительность; сельское хозяйство. 